\title{
Utilization of protected cultivation for crop production and preservation in India
}

\author{
Sharma, A. ${ }^{1} \bowtie$, Raghavan, M. $^{2}$, Zhang Shi ${ }^{3}$ and Nguyen Tran Hai Bang ${ }^{4}$
}

Received: 19.03.2021

Revised: 28.04.2021

Accepted: 10.05.2021

\begin{abstract}
The present paper discusses about the applications of protected cultivation for crop activities, and technology utilization in India. The crop production, management, plant propagation are applied at protected cultivation in sustainable agriculture. The advancement of technology is boosted in protected cultivation that transforms sustainable agriculture into modern agriculture. The various agricultural crops are practiced naturally after research progress in protected cultivation. The various sophisticated technologies like scientific farming, vertical farming, vertical farming with hydroponics, organic farming, micro-irrigation, organic fertigation, chemical fertigation, IPM, IDM, INM, farm machines \& tools, aquaponic, micro green farming, in-situ crop preservation, azolla production and seed production are utilized in crop activity and academic \& research. The modern technologies are constituted in protected cultivation that transforms modern agriculture into smart agriculture. It will promote land, water, waste land conservation. It would reform nutrient content of the soil, forbids soil erosion and soil pollution. It will provide employment opportunities, agricultural business, food security and rural development in India.
\end{abstract}

Key words: Utilization, Protected Cultivation, Production, Preservation

\section{Introduction}

Protected cultivation is a horticulture science technology that grows agricultural and \& horticultural crops and preserves crops under relevant climatic factors. It grows flower crops, vegetable crops, spices and medicinal \& aromatic plant under suitable climatic conditions. It preserves mother crops, horticultural mother crops and endangered species. The crop cultivation and crop preservation are possessed in poly house technology and shed net house. The low cost. Medium cost and high cost are applied for crop cultivation and crop production. The protected cultivation was initiated more than 200 years ago and the European countries were specialized in crop cultivation. The Mediterranean basin countries like Italy, Spain and Morocco were used first plastic technology for crop production after World War II. The glass shielded greenhouses are utilized.

\section{Author's Address}

${ }^{1}$ School of Agricultural Sciences, RNB Global University, Bikaner, Rajasthan

${ }^{2}$ Department of Fruit Science, CHF, Central Agricultural University, Pasighat, Arunachal Pradesh

${ }^{3}$ Sheng Yang Agriculture University and China University of Political Science and Law, China

${ }^{4}$ Cuu Long Delta Rice Research Institute, Can Tho, Vietnam

E-mail.: avinashcau@gmail.com traditionally by the Netherlands (Holland) for flowers and vegetables production The world is covered of 20 mha under protected cultivation in that Japan has the highest poly house cover area of 54000 ha (table 1) (Chakraborty and Laxmi, 2015). The protected cultivation was started in India during 1980 that used for research activities. The National Committee on the use of plastics in Agriculture (NCPA, 1982) advised for adopting plastic technology in the country. The centre for plastic cultivation technology body established protected cultivation house in 1998-99 year for production and development. The protected cultivation was adopted more than 2.15 lakh ha till 2017-18. The area under protected cultivation is highest in Chattisgarh, Odisha, Andhra Pradesh, Gujarat, Madhya Pradesh and Maharashtra (Saravaiya et al., 2014; Prakash et al., 2019).Protected cultivation assists into the commercial sector as well as institution sector. The commercial protected cultivation are utilized for agricultural business and institutional applications and institutional protected cultivation are used for academic and research purpose. The crop production, crop preservation, crop multiplication and crop management, IPM, INM, and IDM are 
Table 1: Approximate area (ha) under greenhouses

\begin{tabular}{|c|c|}
\hline Countries & Area (ha) \\
\hline Japan & 54000 \\
\hline China & 48000 \\
\hline Spain & 25000 \\
\hline South Korea & 21000 \\
\hline Italy & 18500 \\
\hline Turkey & 10000 \\
\hline Holland & 9600 \\
\hline USA & 4000 \\
\hline Israel & 1500 \\
\hline India & 525 \\
\hline
\end{tabular}

utilized in sustainable agriculture. The advancement of technology emerges in modern agriculture in that micro-irrigation (sprinkler irrigation, drip irrigation), fertigation, organic farming, vertical farming, vertical farming with hydroponics, in-situ crop preservation, nursery raising, water conservation, research, etc. It will promote waste land utilization. It prevents land degradation and soil pollution. It would reform problematic soil and nutrient of the soil (figure 1).
It would generate employment and conserve endangered species. Singh et al. (2015) explained that protected cultivation utilized for crop production in controlled climatic conditions and uses for off season vegetables production and horticulture crop production. It utilizes scientific technology like quality seeds, fertilizers, plant protection measures etc in poly house and shade net house. It mitigates soil exploitation, water exploitation and land degradation secures waste land (Prabhakar et al., 2017). Debora et al. (2018) described that protected cultivation applies farm machine \& tools, micro-irrigation and agricultural technologies for smart agriculture. Amit et al. (2020) elucidated that the vegetable production was conducted organic farming with novel technology into low cost poly house and shade net house.

The protected cultivation applies classical and modern technology of agricultural activities. It is capable to fulfill past goals in the modern period. Some of the protected cultivations are., i) Poly house technology/cultivation ii) Shade net technology/cultivation

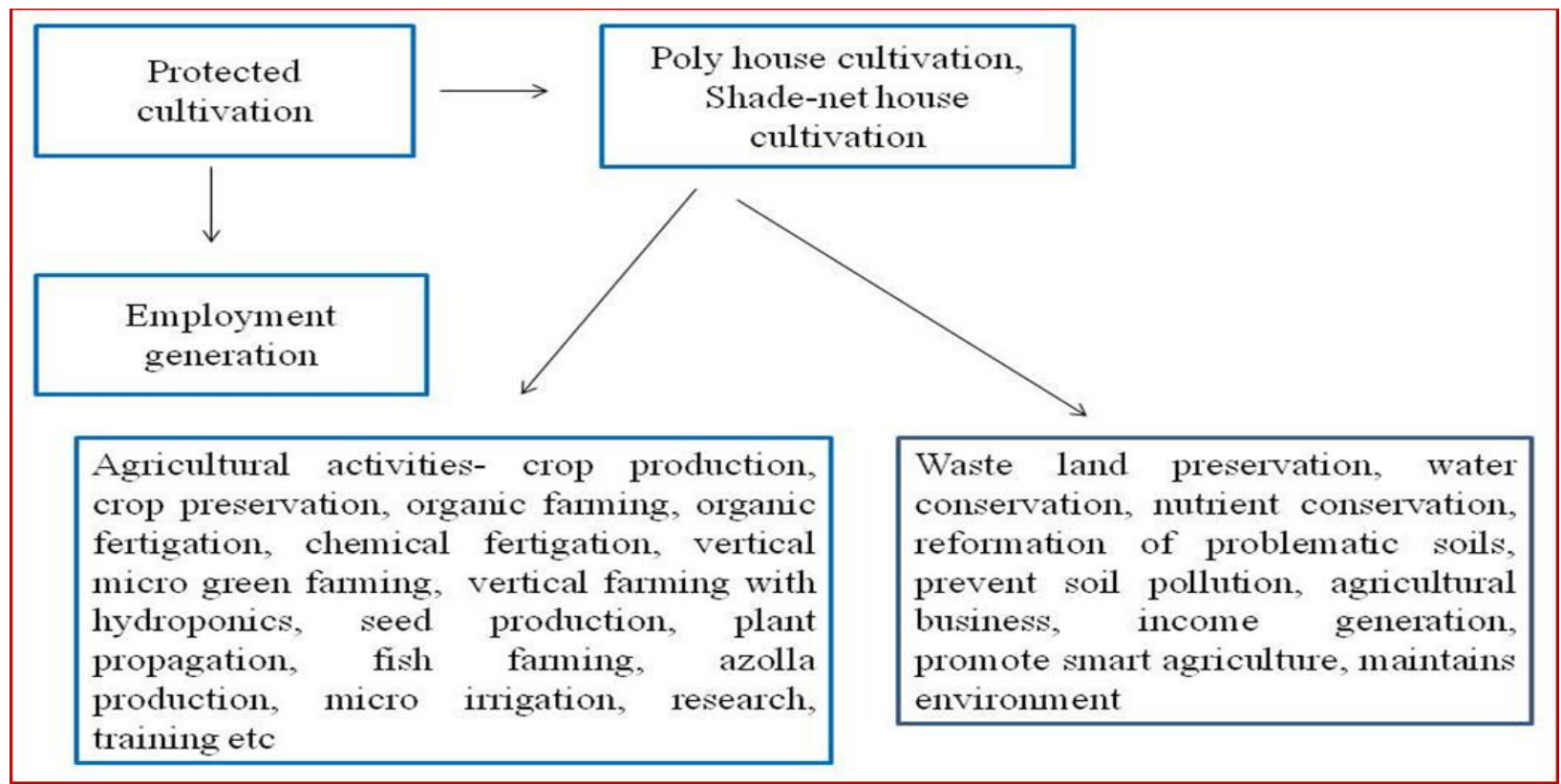

Figure 1: Goal and smart agricultural activities of protected cultivation.

i) Polyhouse technology/cultivation

Poly house technology is accepted technology for crop production and preservation in India. It constructs practically in three forms i.e., low cost poly house, medium cost poly house and high cost poly house. The low cost poly house is constructed with 700 gauge UV stabilized plastic sheet, bamboo, ropes and nails. The medium cost poly house is constructed with 800 gauges of the plastic sheet, $15 \mathrm{~mm}$ GI pipe. The shape of medium cost 
poly house is Qunoset-shaped poly house. The exhaust fan, ventilator and humidifier are available for controlling temperature. The life span of medium cost polyhouse is 20 years. The high cost poly house is constructed with iron/aluminium material and shape is dome shape/conical shape. It is highly durable than medium cost poly house and low cost poly house. The poly house utilized in the old trend for crop production, preservation and management but the advancement of agricultural technology, the several agricultural technology like land pattern development, vertical farming, vertical farming with hydroponics, micro-irrigation (sprinkler, drip irrigation), organic farming, azolla culture, cop preservation, duster \& sprayer equipments, path development, nursery raising, farm machine \& tools, IPM etc. practically involved for healthy crop production, scientific farming and smart agriculture (figure 2). It tangibly imparts in soil conservation, water conservation, nutrient reformation. It prevents soil problems, soil pollution, maintains environment, provides education \& training and generates employment for livelihood and security.
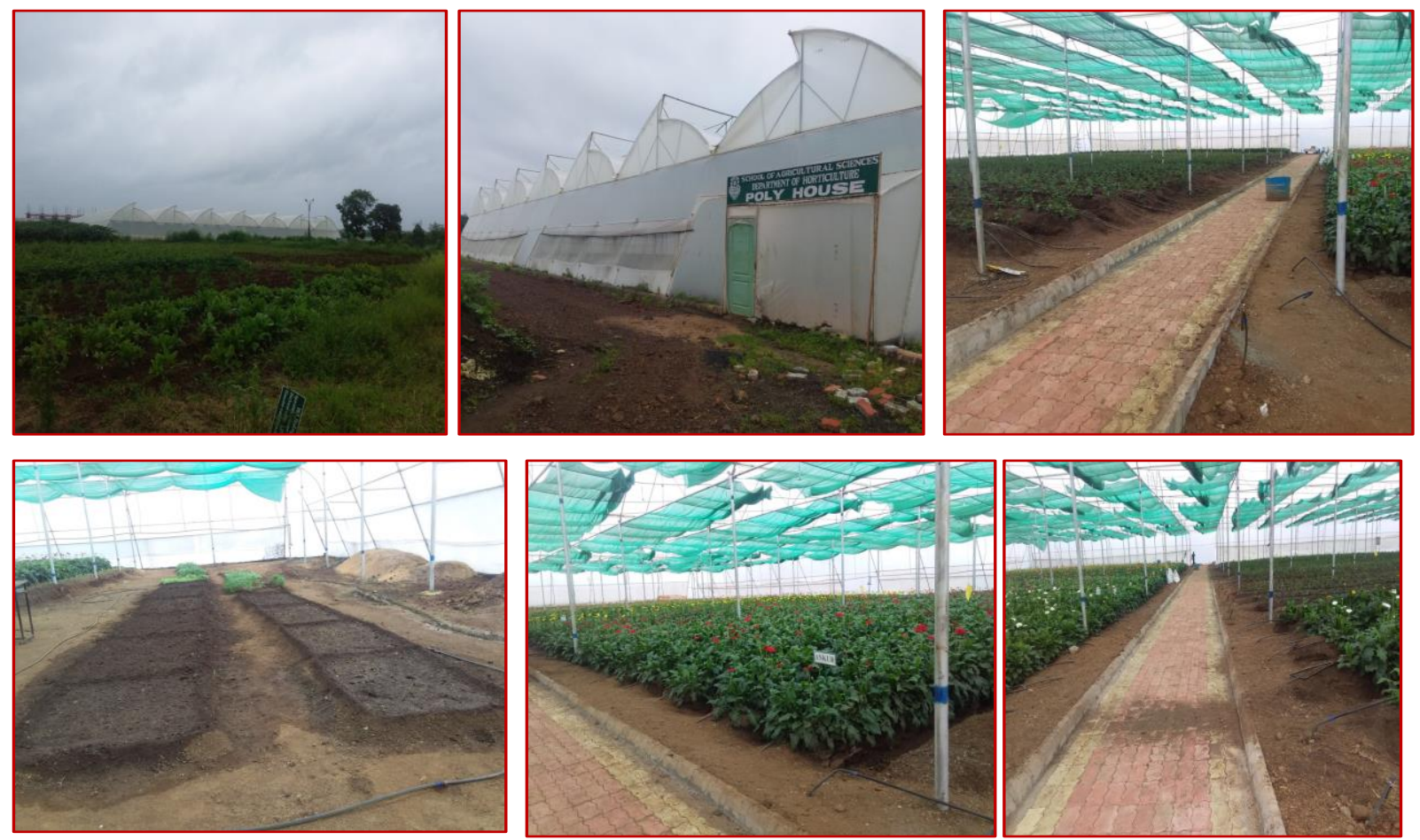

Figure 2: Crop production and technology involvement in Qunoset-shaped high cost polyhouse

\section{ii) Shade net technology/cultivation}

Shade net house technology is reliable technology for the modern period. It is constructed with GI pipes, angle iron, wood/bamboo and plastic net. The plastic nets are prepared with polyethylene thread with UV treatment. The shade net plastic material is available at different percentages i.e., $15 \%, 35 \%, 40 \%, 50 \%, 75 \%$ and $90 \%$ that prevent the entry of percent of light. The shade net house is available in different colours i.e., white, black, red, blue, yellow and green and in combinations Green $\times$ Black, Black $\times$ Black, White $\times$ Black, White $\times$
Green, Green $\times$ Green. The shade net house utilized for crop multiplication and crop preservation in classic period. Now, the advanced technology like organic farming, vertical framing, micro-irrigation (drip, sprinkler irrigation), research, crop production, vertical farming, vertical farming with hydroponics, azolla farming, IPM etc practically utilizes at shade net house in the modern period. It practically possesses land conservation, nutrient reformation and water conservation. It resolves problematic soils and maintains ecology. It 
encourages scientific practices and transforms improvement, Spirullina production, seedling modern agriculture into smart agriculture. It production, crop production, training, provides training and education to students and demonstration, hydroponics system, automatic farmers. It generates employment for resources and irrigation system, aquaponic (fish production), off human development (figure 3). The new age season crop production, organic farming, hanging protected cultivation magazine discussed that the pot production, etc. are presently utilized at poly new agricultural tools like LED for tomato quality house and shade net house in India
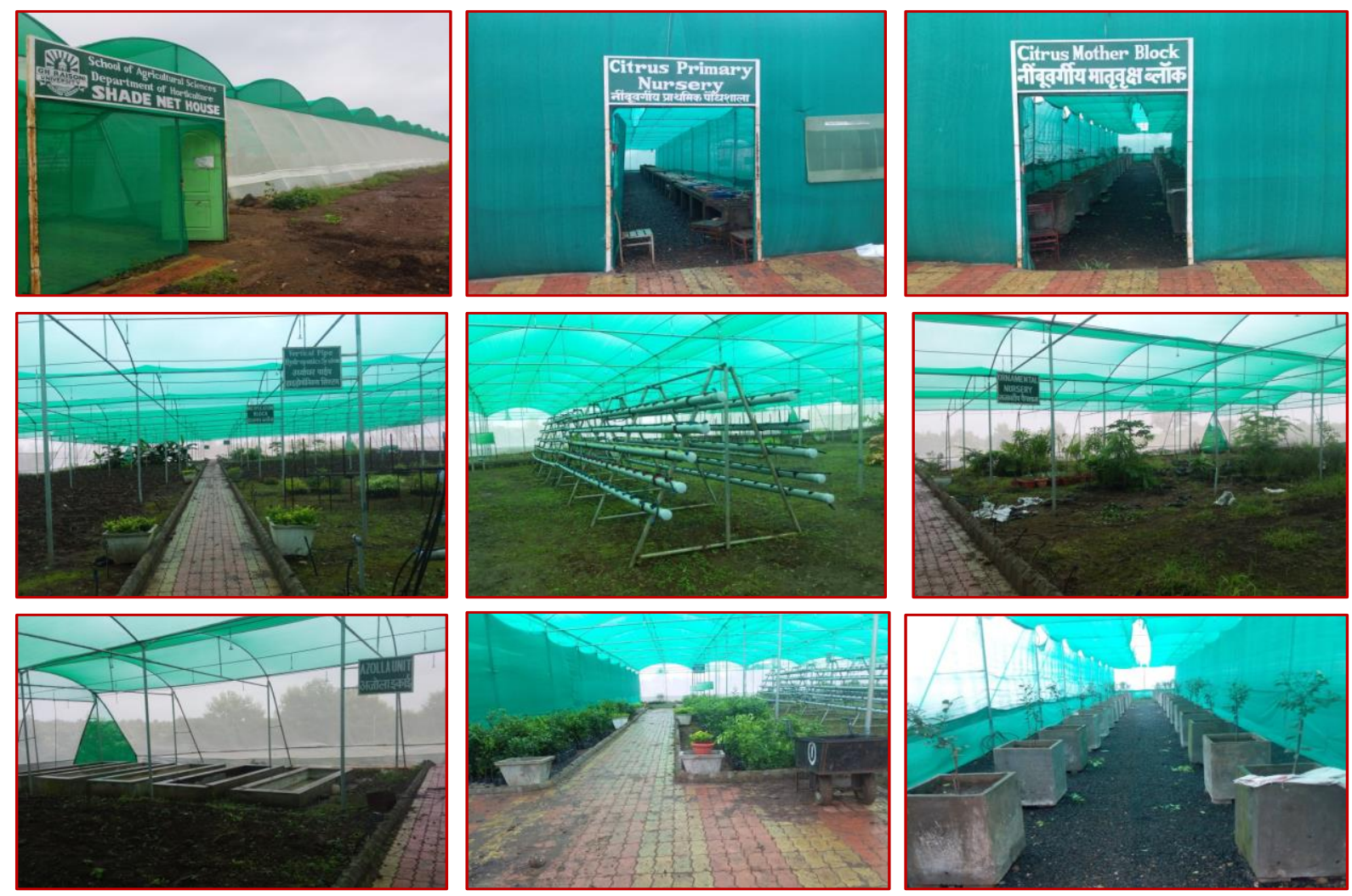

Fig. 3: Crop production and technology involvement in green $x$ white shade net house

(Brahma et al., 2015). The micro farming (small crop production), underutilized vegetables, robotics, aquaponic with solar \& photo voltaic cells, vertical farming, vertical farming of micro green plants with LED, urban farming, seed production, organic farming, tunnel farming, organic fertigation, woven polyethylene, tissue culture plant, electric tractor are currently applied in poly house in the world and India (Brahma et al., 2020).

\section{Conclusion}

The protected cultivation provides advantage in agricultural business and education activities. It encourages organic farming and land reformation, involves various novel agricultural technologies for farmers growth and human resource development. It will progress raw material \& product production and income of polymer industry. Protected cultivation can be prepared with low cost of bamboo raw materials. It balances ecology as well as ecosystem. It transforms modern agriculture into smart agriculture and generates employment for resource and human growth.

\section{Acknowledgement}

The author acknowledges that the polyhouse and shade net house provides working facilities at University campus in Saikheda, Madhya Pradesh. 


\section{References}

Amit, K., Sachin, T. and Neeraj, K. 2017. Protected Cultivation of Vegetable Crops. Dimensions of agricultural science, 62-68.

Brahma, S. 2015. New Age Protected Cultivation, magazine devoted for the advancement of protected cultivation technology. ISPC, CPCT, IARI, New Delhi, pp. 1-40.

Brahma, S. 2020. New Age Protected Cultivation, magazine devoted for the advancement of protected cultivation technology. ISPC, CPCT, IARI, New Delhi, pp. 1-40.

Chakraborty, H. and Laxmi, N. S. 2015. Prospects of Protected Cultivation of Vegetable Crops in North Eastern Hilly Region. International Journal of Basic and Applied Biology, 2(5): 284-289.

Debora, D. F. V., Flávia, M. and Clemente, V. T. 2018. Harvest-Expedition on Protected Cultivation: characterization and prospective study of the challenges and solutions associated with the protected cultivation of vegetable crops. Horticultura Brasileira, 36: 431-438.

Prabhakar, I., Vijayaragavan, K., Premlata, S., Balraj, S., Janakiram, B. L., Manjunatha, Seema, J. and Sekar, I.
2017. Constraints in adoption and strategies to promote polyhouse technology among farmers: A multi-stakeholder and multi-dimensional study. Indian Journal of Agricultural Sciences, 87(4): 485-90.

Prakash, P., Pramod, K., Amit, K., Awani, K. S. and Anbukkani, P. 2019. Progress and Performance of Protected Cultivation in Maharashtra. Indian Journal of Economics and Development, 15(4): 555-563.

Saravaiya, S. N., Patel, N. B. and Sanjeev, K. 2014. Protected Cultivation: Future Technology for Vegetable Crops. Shodh Chintan, 6: 216-278.

Singh, V. K., Ranjan, S., Anurag, S. and Manoj, K. S. 2015. Protected cultivation of Horticultural crops. Technical Bulletin, Central Institute for Subtropical Horticulture, Indian Council of Agricultural Research, Lucknow, pp. 127.

Sylvan, H., Wittwer. and Nicolas, C. 1995. Protected Cultivation of Horticultural Crops Worldwide. Horticulture Technology, 5(1): 6-7. 